\title{
INDEX TO VOL. L.
}

Part I. - general index.

\author{
Abnormal and degenerate, 542 \\ Adolescent insanity in Dorset, 266 \\ After Care Association, 311 \\ After-care of friendless patients discharged from asylums, 455 \\ Alcohol in health and sickness, 672 \\ Alcoholic antomatism, 285 \\ Alcoholic question, 580 \\ Alcoholism, social causes of, 417 \\ Anæmia, pernicious, mental symptoms, 771 \\ Annual Meoting, 750 \\ Anthropolog , 155, 328, 542, 759 \\ Anti-serums in acute insanity, experimental use of, 259 \\ Anti-vivisection, 102 \\ Armagh District Asylum, historical notes on, 806 \\ Asylum reports, 674 \\ Workers Association, 599 \\ Asylums, auxiliary, 112 \\ " county and borough, 120 \\ " laboratory, 111 \\ Innatic as hospitals, 568 \\ Attendants and nurses, training of, 788
}

Bacteriological researches on the dust in music-halls, 573

Ballinasloe appointment, 595

" asylum, cruelty in, 530 once more, comic relief, 597

Blind" deaf-mute, Marie Heurtin, 132; Agmes Halonen, 336

Blood-serum of epileptics, alleged toxic and therapentic properties of, 179

Bones, fragility of, in the insane, 188

Brain and cord, new method of fixing for examination, 198

" of the late Major J. W. Powell, 330

old and new investigations upon, 546

") weights of notable men, 329

Brains of three brothers, simultaneons examinations of, 328

British Medical Association - section of psychological medicine, 808

Bromipin, therapeutic action of, 567

Cakebread, Jane, psychology of, 218

Care of weak-minded in infancy and childhood, 473

Caution cards, use of, in asylums, 250, 816

Cerebellum, localisation of functions, 761

Cerebral aneurysm of remarkable size, 305

" cortex, action of calcium on, 763

function, localisation of, 651

Chalfont Colony Chrosicicle, 599

Cheadle, addition to hospital at, 277

Children, first symptoms of neuropathy in, 564 
Children, knowledge of colours among school, 655

\section{Child's body, 323} tests of normal and abnormal, 157

" psychic life, 323

Chores and epilepey, cerebral localisation of, 549

Christie and others $v$. Simpson and others, 349

Clinical neurology and peychiatry, 162, 331, 556, 766

Coloured hearing, 765

Communicated insanity, occurring in mother and daughter, 297

Congress of experimental peychology at Giessen, 764

Consciousness, double, Report of committee, 500

"of the ego, pathology of, 551

Constipation, obstinate, due to plum-stones in rectum, 307

Constitutional peychoses, 143

Contrary actions, 560

Corpus callosum in alcoholic subjects, 345

$" \quad "$ deficiency of, 548

" $\quad$ fibres of, after bullet wound, 545

Correspondence, Christie and others, etc., from Dr. T. R. Ronaldson, 349

" from Dr. R. S. Stewart, 599

" on nursing, from Dr. Urquhart, 816

" on nursing by Mr. Bloomfield, 816

" on nursing by Mr. Bloomilical tables, from Dr. Yellowlees, 816

Cortical" excitability and epileptic phenomens by decalcifying agents, 155

Crime and the methods of combating it, 322

". hypnotism, 107

Criminal responsibility and degeneracy, 808

Criminality in Sardinian lunatics, 773

, of the insane, 773

Deaf, dumb, and blind, cases of, 132, 336

Degeneration, influence of urban life in producing, 569

" obstetrical stigmata of, 159

" significance of stigmata, 541

Degenerescence, physical signs of, 544

Delirium, grave, critical study of, 558

Dementia, influence of heredity, 561

" præcox, 516, 813

" senile, 558

" with multiple sclerosis, 560

Denmark, progress of psychiatry, 142

Depersonalisation and possession, 652

Double consciousmess, 698

Dowie, Dr., 527

Dreaming, peychology of, 658

Drug therapeutics in asylumns, 105

Early treatment of insanity, value of, 576

Education of the individual as preventing insanity, 578

Educational treatment of young epileptics, 662

Employment of patients in asylums, 581

Epilepsy : cessation of fits under salicin, 302

"treatment of, general survey, 565

Epileptic, complex synøsthesia in an, 338

Epileptics, educational treatment of, 662

Epileptiform type, cases of, 513

Etiology of insanity, 159

Eye region : Mnnk's visual sphere, 547

Family care of insane, 111, 782

Fatigue, meäun" need of, in Ireland, 461 
Fiscal questions-auxiliary asylums, 112

Fragilitas ossium in the insane, 188

France, progress of peychiatry in, 143

General paralysis, see Paralysis

General practitioner, relation of, to treatment of insanity, 568

Genius, British, 318

Germany, progress of psychiatry, 147

Gheel, gossip about, 53

Graves's disease and its relation to the psychoses, 659

Hair, growth of, in lumbo-sacral region in case of spina bifida, 162

Hallucinations duplicated, 158

" pathogenesis of, 768

Hallucinatory insanity, 169

" of traumatic origin, 478

Hearing, unilateral hallucinations of, 766

Heredity in the pathogenesis of dementia, 561

Heredity, biological aspect, 809

Hickman, Miss, 101

High altitudes for nerve cases, 178

Histological Report, 510

Horton Asylum scandal, 751, 814

Humours of Irish asylum committees, 355

Hypnotic action of neuronal, 776

Hypnotism and crime, 107

Hysteria, relation to insanity, 272

Hysterical mutism without agraphia, 344

" persons, evidence in forensic practice, 347

Idiocy and insanity, surgery of, 779

" microcephalic, otc., 69

Illusion of weight in abnormal persons, 156

Imagination, 137

Imbecile, phenomenal talent for counting, 562

Imbecility, Mongolian 32

Incipient insane, care of, 181

Insane, general evolution of the case of the, 183

" means of allaying excitement in, 176

" placing under restraint and powers of police to intervene, 774

" settlement for family care of, 181

Insanity after acute and chronic infectious diseases, 772

" by contagion, 342

"geographical distribution of, 140

" in the army during peace, 326

simulation of, 347

" treatment of, 176, 565

" value of saline injections in, 585

Intemperance, 117

Intermational home relief conference, 317, 358, 521

Irish asylums conference, 109

Italy, progress of psychiatry, 149

Juvenile insanity in dementia precox, 639

Katatonia, 171

Kinsel, John, case of, 331

Korsakow's psychosis, 83

Laboratory for the study of abnormal cases, $\mathbf{5 2 9}$ 
Latent prophet, 527

Leucocyte counts in mental diseases, 400

Library, the, 526

Locks with glass covering, 576

London County Asylums, management of, and Horton Asylum scandal, 751

Luke's Hospital, St., history of, 37

Lumbar puncture, year's experience of, 776

Lunacy Bill, 524

value of in mental disease, 778

" and the law, 119

" Legislation, 523, 698

" reform in Melbourne, 108

Lunatics troublesome, 783

Mania acute, intercurrent disease affecting, 283

" study on, 340

Martyrology of psychiatry, 308

Medico-legal cases -

Annie Campbell Brabazon, 353

Hutchinson $v$. Walsh and another, 200

Rex v. Rodgers, 588

Rex $v$. Tramways, 591

Medico-Psychological Association Meetings, 185, 352, 581, 784

Melancholia, origin and pathology of some cases, 161

Memory, unusual alteration of, in an insane alcoholist, 338

Mental and moral effects of the South African War, 1

" disorders, several forms of, 332

" symptoms, relation to bodily disease, 13

"

"weakness, pathological origin of doubt in, 334

Mongolian imbecility, 32

Moral insanity, medico-legal case, 573

Motor centres, true, 760

Movements, psychological aspects of, 138

Nervous patients, treatment of, 147

Neurology, epitome, 155, 760

Neüronal, 776

clinical, and psychiatry, 162, 331, 556

Neurosis of anxiety, 341

Nose, price of, 596

Nurses, registration of, 451

" training of, 788

Nursing, male and female, 816

Obituary notices-Bateman, Sir F., 820; Benham, Dr. H. A., 821 ; Fletcher, R. V., 358; Garner, W. H., 357 ; Inderwick, Mr. F. A., 820 ; Richards, J. P., 358, 600 Obsessions, 234.

Obsession and delusion, 341

Occipital fossa, median, 155

Open-air treatment of acute insanity, 579

Paraldehyde delirium and effects of paraldehyde, 180

Paranoia, doctrine of, 166

” among Brazilian negroes, 169

" presidential address on, 607

Paranoiac delusion ; Stirner's ideas, 167

Paralysis, general, 75, 76, 145, 146, 161, 433, 437

Pathology of insanity, 345

Physiological psychology, 156, 551, 764.

Porencephalus with hæmorrhagic pachymeningitis, 504

Presidential Address, 1904, by Dr. Percy Smith, 607 
Private or pauper? 312, 534

Prodromata of the sychoses, 207

Psendo-hallucinations, 163

Psychology of Jane Cakebread, 219

"

", hallucinations, 633

Reaction time, variability of, 766

Rhythms, motor, visual and applied, 135

Saline injections in mental disease, 585

Sex and head size, 324

Sexual psychopathies, 539

Skull, Italian, capacity of, 759

Sleeping sickness, the Trypanosoma of, 262

Sociology, 181, 347, 569

Spain, progress of psychiatry, 153

Spencer, Herbert, Mr., 99

Spina bifida occulta, 162

Spirit mediums, legal and psychological judgment of, 570

St. Patrick's Hospital, notes on, 196

Statistical tables, 672, 797

Stress, 281

Surgery of idiocy and insanity, 779

Syphilis contracted in early general paralysis, 161

Temperature sensations, perversion of, 344

Thyroid extract treatment. 78

Tics and their treatment, 320, 344

Traumatic origin of acute hallucinatory insanity, 478

Traumatism and general paralysis, 433

Trympanosoma of sleeping sickness, 262

Treatment of insanity, 176, 565, 774

United States, progress of psychiatry, 139

Vaso-motor waves and reaction time, 764

Veronal, 775

Vision, 537

poisoning, 775

Wages, lunacy, and crime in S. Wales, 64

Youghal asylum, 203, 528

Part II.-original articles.

Baker, Dr. J., general paralysis and crime, 437

Bruce, Dr. Lewis C., experimental use of anti-serums in acu te inssnity, 259

$" \quad " \quad$ effect of acute intercurrent disease on mania, 283

$"$ " " leucocyte counts in mental disease, 409

Campbell, Dr. A. W., histological studies on the localisation of cerebral function, 651

Clouston, Dr., prodromata of the psychoses, 207

Cole, Dr. S. J., Korsakow's psychosis, 88

Drapes, Dr. T., hallucinatory insanity of traumatic origin, 473

Edridge-Green, Dr. F. W., relation of hysteria to insanity, 272

Eustace, Dr. H. M., case of dementia procox, 616

Fennell, Dr. C. H., Mongolian imbecility, 32

Findlay, Dr. J. W., histological report on case of porencephalus, 504 
Johnstone, Dr. J. C., after-care of friendless patients, 455

Jones, Dr. R., psychology of Jane Cakebread, 219

" " trypanosoma of sleeping sickness, 262

Kemp, Dr. Norah, treatment with thyroid extract, 78

Lord, Dr. J. R., communicated insanity, 297

Marnan, Dr. J., caution cards in asylums, 250

Mercier, Dr. C., stress, 281

" the statistical tables, 672

Middlemäs, D̈r. J., developmental general paralysis, 76

Monro, Dr. T. K., permanent amaurosis with optic atrophy and opilepsy in case of porencephalus with hæmorrhagic pachymeningitis, 504

Nolan, Dr. M. J., clinical and pathological notes, 69

Norman, Dr. C., gossip about gheel, 53

" " " need for family care of persons of unsound mind, 461

Peebles, Dr. A. S. M., leucocyte counts in mental disease, 409

Rainsford, Dr. F. E., cases of epileptiform type with unusual characteristics, 513

kaw, Dr. N., relation of mental symptoms and bodily disease, 18

Rawes, Dr. W., St. Luke's Hospital, 37

Rayner, Dr. H., care of weak-minded in infancy and childhood, 473

Rice, Dr. D., cerebral aneurysm, 305

Rorie, Dr. G. A., adolescent insanity in Dorset, 266

Shaw, Dr. J., obsessions, 234

Shuttleworth, Dr. G. E., the educational treatment of young epileptics, 662

Smith, Dr. R. Percy, presidental address on Paranoia, 607

Stewart, Dr. R. S., mental and moral effects of South African war, 1

\# relationship of wages, lunacy, and crime in South Wales, 64

Stoddard, Dr. W. H. B., the psychology of hallucination, 633

Sullivan, Dr. W. C., alcoholic automatism, 285

" social causes of alcoholism, 417

Sutcliffe, Dr."A., addition to the hospital at Cheadle, 277

Thompson, Dr. D. G., remarks on Nurses' Registration Bill, 451

Veitch, Dr. J. O., obstinate constipation from plum-stones in rectum, 307

Vincent, Dr. W. J., epilepsy : cessation of fits under salicin, 302

Wilson, Dr. A., Report of committee on case of double consciousness, 500

" a case of double consciousness, 699

\section{PART III.-REVIEWS.}

Arnould, Louis, Une ame en prison: histoire de l'education d'une avenglesourde-meutée de naissance, 132

Aschaffenburg, Prof., Dar verbrechen und seine Bekämpfung, 322

Bloch, Dr. Iwan, Beiträge zur E⿰tiologie der Psychopathia sexualis, 539

Dugas, Prof. L., L'imagination, 137

Ellis, Dr. H., A study of British genius, 318

Evensen, Dr. H., Ungdomsaarenes sindssygdomme i dementia præcox, 539

Féré, Dr. C., Travail et Plasir, 536

Groos, Prof. K., Das seelenleben des kindes, 323 
Iberg, Dr. G., On insanity in the army during peace, 325

Marchand, Dr. L., Le Gotat, 136

Meige, Drs. H. and E. Feindel, Les tics et leur traitement, 320

Miner, Dr. J. B., Motor, visual, and applied rhythms, 135

Mobins, Dr. P. J., Sex and head size, 324

Nuel, Dr. J. P., La vision, 537

Report of Commissioners in Lunacy, England, 119

" " " Scotland, 124

" "Inspectors of Lunatics, Ireland, 127

") ", the Cambridge anthropoligical expedition to Torres Straits, vol. v, 758

Lergi, Prof. G., L'origine dei fenomeni psichici, 321

" "L'evoluzione umana, 321

Stratz, Dr. C. H., der Korper des Kindes, 323

Swoboda, Dr. H., The periodicity of the human organism and its physiological and biological significance, 756

Traité de pathologie mentale, 542

\section{AUTHORS REFERRED TO IN EPITOME.}

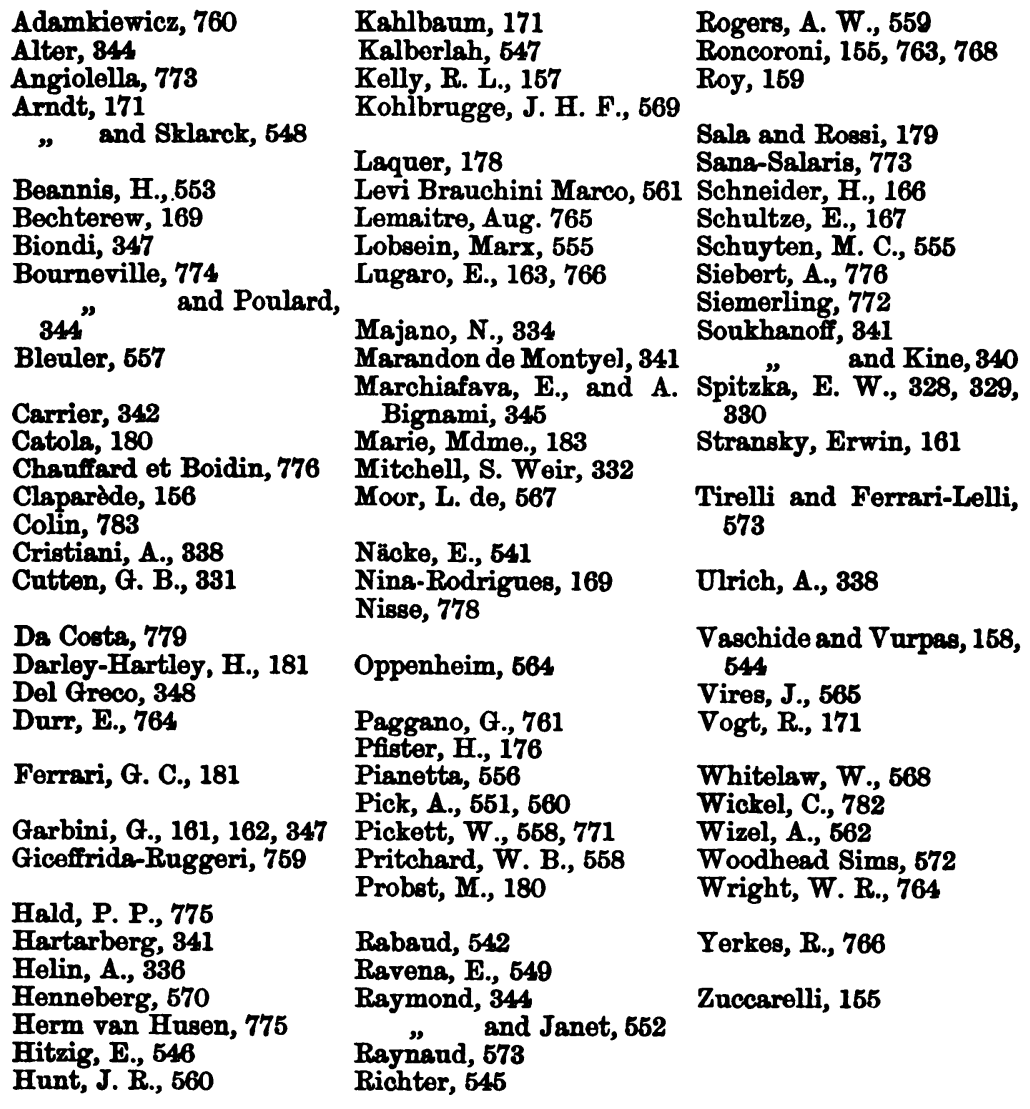




\section{ILLOSTRATIONS.}

Chart to illustrate Dr. Stewart's paper, 69.

Four photographs to illustrate Dr. M. J. Nolan's paper, 70, 72.

Photograph to illus trate Mr. Rice's case, 307.

Eighteen diagrams to illustrate Dr. Stoddart's paper, 685-639, 643-647.

PRINTED BY ADLARD AND SON, LONDON AND DORKING. 